\title{
Organic carbon distribution and cycling in the Quercus glauca forest at Gotjawal wetland, Jeju Island, Korea
}

\author{
Young-Sub Han ${ }^{1,2}$, Eung-Pill Lee², Jae-Hoon Park², Seung-Yeon Lee², Soo-In Lee² and Young-Han You ${ }^{*}$ (D)
}

\begin{abstract}
Background: This study was conducted from March 2011 to February 2013 in order to evaluate the ecosystem value by examining the organic carbon distribution and cycling in the Quercus glauca forest, evergreen oak community at Seonheul-Gotjawal, Jeju Island.

Results: The amount of organic carbon distribution was 124.5 ton C ha ${ }^{-1}$ in 2011 and 132.63 ton C ha ${ }^{-1}$ in 2012 for aboveground biomass. And it was 31.13 ton $C$ ha $^{-1}$ in 2011 and 33.16 ton C ha ${ }^{-1}$ in 2012 for belowground biomass. In total, the amount of organic carbon distribution in plants was 155.63 and 165.79 ton $\mathrm{C} \mathrm{ha}{ }^{-1}$ in 2011 and 2012, respectively. In 2011 and 2012 respectively, the amount of organic carbon distribution was 3.61 and 6. 39 ton $\mathrm{C} \mathrm{ha} \mathrm{s}^{-1}$ in the forest floor and it was 78.89 and 100.71 ton $\mathrm{Cha}{ }^{-1}$ in the soil. As shown, most carbon was distributed in plants. Overall, the amount of organic carbon distribution of the Q. glauca forest was 238. 13 ton $\mathrm{C} \mathrm{ha} \mathrm{C}^{-1}$ in 2011 and 272.89 ton $\mathrm{Cha}^{-1}$ in 2012. In 2011, the amount of organic carbon fixed in plants through photosynthesis (NPP) was 14.22 ton $\mathrm{C} \mathrm{ha}^{-1}$ year $^{-1}$ and the amount of carbon emission of soil respiration was 16.77 ton $\mathrm{C} \mathrm{ha}^{-1}$ year $^{-1}$. The net ecosystem production (NEP) absorbed by the Q. glauca forest from the atmosphere was 5 ton $\mathrm{C} \mathrm{ha}^{-1}$ year $^{-1}$.
\end{abstract}

Conclusions: The carbon storage value based on such organic carbon distribution was estimated about 23. 81 mil won ha $^{-1}$ in 2011 and 27.29 mil won ha ${ }^{-1}$ in 2012, showing an annual increment of carbon storage value by 3. 48 mil won ha ${ }^{-1}$. The carbon absorption value based on such NEP was estimated about 500,000 won ha-1 year ${ }^{-1}$.

Keywords: Dongbaekdongsan(Mt.), Evergreen broad-leaved forest, Carbon budget, Soil respiration, Ecosystem service

\section{Background}

Over past decades, the environmental issues have reached an alarming level around the globe and the climate change has become one of the major problems (Lee 2013). It is widely known that carbon dioxide $\left(\mathrm{CO}_{2}\right)$ plays a major role in the greenhouse effect. As result of acceleration in global warming, the global average temperature is expected to rise by approximately $3.7^{\circ} \mathrm{C}$ and sea level by approximately $63 \mathrm{~cm}$ by the end of twenty-first century in relation to the level before the industrial revolution (Jin et al. 2000; IPCC 2013).

In 1992, the United Nations Framework Convention on Climate Change (UNFCCC) was established regulating

\footnotetext{
* Correspondence: youeco21@kongju.ac.kr

${ }^{2}$ Department of Biology, Kongju National University, Kongju, Republic of South Korea

Full list of author information is available at the end of the article
}

carbon credit, low-carbon green growth, green technology, and energy reduction. Moreover, Kyoto Protocol, an extension to UNFCCC, was announced in 2005 to regulate the emission of greenhouse gases emitted by the developed countries. In 2013, South Korea enacted "Act on The Management and Improvement of Carbon Sink" and started various carbon reduction programs to maintain and improve the function of forests as carbon sinks. Based on the amount of $\mathrm{CO}_{2}$ absorbed by forests, the government is also operating 'Forest Carbon Offset Scheme' to counter the amount of $\mathrm{CO}_{2}$ released from industries (Kim 2015).

One of the ways that can be used to reduce the greenhouse gases is to increase the amount of carbon sequestration in forests and soil. Specifically, an effective forest management or a designation of conservation area through the government policy can contribute towards improving the carbon control function of the nature and, through this, 
mitigate the climate change because $65 \%$ of the landmass in South Korea is covered by forests (Roh et al. 2016). The advantage of utilizing the forest as carbon sinks is that its ability to absorb greenhouse gases is not limited like the emission reduction programs used in other industries and the amount of greenhouse gases absorbed is relatively consistent. Also, the forests ability to absorb greenhouse gases can be managed and be improved. Utilizing the forests as carbon sinks can not only prevent global warming through efficient management but also provide diverse public benefits, such as conservation of ecosystem, water resources conservation, atmospheric purification, prevention of soil erosion, and recreational environment (Malmsheimer et al. 2008). The public functions of forests cannot be valued easily because there is no reliable way to quantify their value. But, the value of ecosystem, which is generally undervalued, should be re-evaluated (Koo et al. 2012).

Recently, there were various researches under progress attempting to quantify the value of ecosystem considering the type and function of ecosystem services. Typical methods used to quantify ecosystem services are: RUBICODE project (Rationalising Biodiversity Conservation in Dynamic Ecosystems project; Vandewlle et al. 2009) that can assess regions in Europe and countries by using the information based on the ecosystem services-provisioning, regulating, cultural, supporting services-classified by MA(Millennium Ecosystem Assessment) (2005); GUMBO (Global Unified Model of the Biosphere; Boumans et al. 2002) that can provide multi-scale integrated assessment on ecosystem services; and InVEST (Integrated Valuation of Environmental Services and Tradeoffs; Nelson et al. 2009) that can provide regional assessment. In the case of Korea, the public functions of forests were quantified by using the statistical data and onsite survey results (Busan development institute, 2011).

The studies on carbon cycling of forest ecosystem in Korea have been continuously conducted (Lee et al. 2013; Han 2014; Won 2015) but not many studies focused on the carbon stocks of each component, carbon flow between the components, and carbon cycling according to the type of forest vegetation in Korea (Han 2002; Pyo et al. 2003; Lee and Mun 2005). The evaluation of ecosystem services is still at its early stage as it is an extremely complex process (Gitay et al. 2001; Kremen 2005). Currently, there are no studies that have analyzed the social cost of natural resources in terms of ecosystem services although some researchers have conducted environmental-economic studies in an attempt to estimate the change in economic value of possible social costs resulting from the climate change (Wunder 2005; Wattage 2011; Brander et al. 2012). In Korea, the studies on ecosystem valuation can be found in the nonmarket forest resources (Kim et al. 2012) and wetland (Jeong et al. 2013), but the value assessment of carbon cycling is limited only to Quercus mongolica forest (Won et al. 2014) and Pinus densiflora forest in Mt. Worak National Park (Won et al. 2015).

The distribution of Quercus glauca forest is expanding towards higher latitude regions due to increase in temperature and Q. glauca is a dominant species in Dongbaekdongsan(Mt.) at Seonheul-Gotjawal, Jeju Island known for its largest warm-temperate evergreen forest in Korea (Yun et al. 2011). The purpose of this study was to analyze the social cost of natural resources, which could be caused by the climate change, by quantifying the organic carbon distribution and cycling in the Q. glauca forest in terms of ecosystem services.

\section{Methods}

\section{Study site}

The Gotjawal is unique and rare ecosystem. It is formed on rocky areas and has important hydrological function such as the high rainwater percolation and protecting rainwater. And the temperature stays pretty constant all year round due to the underlying ground being made up of lava rock. Also it is a habitat for a variety of plants and animals, including endangered species.

Seonheul-Gotjawal is located in the east of Seonheul1ri, Jocheon-eup, Bukjeju-gun where about $10 \%$ of evergreen broad-leaved trees in Jeju Island are distributed (Kawk et al. 2013). Seonheul-Gotjawal is an unusual ecosystem that has a wetland and high species diversity. Also, Quercus glauca (dominant species), Quercus salicina, Castanopsis cuspidata var. sieboldii, Styrax japonica, Camellia japonica, and Eurya japonica, etc. coexist in this ecosystem (Han et al. 2007).

The Q. glauca forest selected as the study site is located $126 \mathrm{~m}$ above sea level by the north of Meonmulkkag wetland. The stand density and diameter at breast height $(\mathrm{DBH})$ and height $(\mathrm{H})$ of study site were 1700 tree ha $^{-1}, 8.4$ $\pm 3.2 \mathrm{~cm}, 9.0 \pm 1.8 \mathrm{~m}$, respectively. According to the Jeju Regional Meteorological Office located about $16 \mathrm{~km}$ away from the study site, the annual average temperature and the annual rainfall were $15.8{ }^{\circ} \mathrm{C}$ and $1497.6 \mathrm{~mm}$, respectively, for the past 30 years $(1981 \sim 2010)$. The annual average temperature and the annual rainfall over the study period (March 2011 February 2013) were $15.8{ }^{\circ} \mathrm{C}$ and $3757.2 \mathrm{~mm}$. The annual average temperature over the study period was the same as that of the past 30 years, but the annual rainfall was double that of the past 30 years, showing a significant difference.

\section{Biomass and net primary production (NPP)}

In summation method, trees with range of $\mathrm{DBH}-$ from the minimum to the maximum-are selected and cut into various organs to weigh their dry mass. And this method is known as the best method to measure the biomass of forests (Kang and Kwak 1998). However, the summation 
method was not practical in this study because the study site was designated as a Ramsar wetland conservation area. In case of secondary forests, it has been reported that the fitness is relatively high even though the biomass regression equation of an existing forest vegetation is applied to another forest vegetation because the tree density is naturally controlled by interspecific and intraspecific competition (Schmitt and Grigal 1981; Tritton and Hornbeck 1982). Allometric equation, which uses DBH as an independent variable, was used to estimate the aboveground biomass because there could be an error in measuring the tree height due to locational conditions. The allometric equation used in this study is as follows:

Allometric equation for Q. glauca (Jeong et al. 2014)

$$
\begin{aligned}
& \log \mathrm{Ws}=2.4042 \log (D)-1.3045\left(R^{2}=0.9873\right) \\
& \log \mathrm{Wb}=2.6436 \log (D)-1.6232\left(R^{2}=0.9711\right) \\
& \log \mathrm{Wl}=1.5428 \log (D)-1.3692\left(R^{2}=0.7979\right) \\
& \log \mathrm{Wab}=2.3324 \log (D)-0.9181\left(R^{2}=0.993\right)
\end{aligned}
$$

In August 2010, $10 \mathrm{~m} \times 10 \mathrm{~m}$ permanent quadrat was installed in the Q. glauca forest and trees with $\mathrm{DBH}$ greater than $3 \mathrm{~cm}$ were measured every April. The biomass was calculated by substituting the measured $\mathrm{DBH}$ into the allometric equation and NPP $\left(\triangle W=W_{2}-W_{1}\right)$ of branches and stems was estimated by deducting the current year's biomass $\left(W_{1}\right)$ from the last year's biomass $\left(W_{2}\right)$.

Evergreen leaves of $Q$. glauca have different life cycle to those of deciduous trees as they fall every month. The annual production was calculated by collecting the leaves and reproductive organs in the litter trap installed in the study site and the result was converted into per unit area.

Rodin and Bazilevich (1967) reported that belowground biomass accounted for about 15 35\% of aboveground biomass. Therefore, the belowground biomass was calculated by applying $25 \%$ to the aboveground biomass (Johnson and Risser 1974).

The amount of organic carbon of biomass and NPP was estimated at about $45 \%$ of the dry mass (Houghton et al. 1983). The annual organic carbon NPP $\left(\triangle C=C_{2}-\right.$ $C_{1}$ ) for each organ was calculated by deducting present year's organic carbon amount $\left(C_{1}\right)$ from the next year's organic carbon amount $\left(C_{2}\right)$.

\section{Litter production}

Four square litter traps $\left(1 \mathrm{~m}^{2}\right)$ and a circular litter trap (0. $785 \mathrm{~m}^{2}$ ) were installed in the study site to quantify the amount of organic carbon flowing into the forest floor. The leaves in litter traps were collected each season and they were divided into leaves, branch and bark, reproductive organs (flower and fruits), and miscellaneous. Then, they were weighed after drying them in the dryer for over $48 \mathrm{~h}$ at $65{ }^{\circ} \mathrm{C}$. The litter production per unit area was calculated based on the dry mass of the collected litter.

\section{Forest floor}

Four $25 \mathrm{~cm} \times 25 \mathrm{~cm}$ smaller quadrats were randomly installed outside the permanent quadrat to quantify the amount of litter and organic carbon in the forest floor. The litter layer was then divided into litter (L) layer and fermentation (F) layer for collection. L- and F-layers were distinguished according to the degree of decomposition. The collected leaves were weighed after drying them in the dryer for over $48 \mathrm{~h}$ at $65{ }^{\circ} \mathrm{C}$. The amount of forest litter per unit area was calculated based on the dry mass of collected leaves on the forest floor.

\section{Soil collection and organic carbon analysis}

The soil was collected from three different locations outside the permanent quadrat every season to quantify the amount of organic carbon in soil. According to Song and Yoon (2002), Gotjawal is characterized by thick layers of rocks in various sizes and by thin layer of soil. Thus, the average soil depth was calculated by considering the rock ratio and soil thickness. And the soil was collected every $10 \mathrm{~cm}$ in depth up to $20 \mathrm{~cm}$ at three different spots. The gravel content ratio of collected soil was calculated by drying the soil in the shade and filtering it with $2 \mathrm{~mm}$ net. The obtained value was used in the organic carbon analysis. $5 \mathrm{~g}$ of soil sample dried under the shade was weighed after drying it in the dryer for over $48 \mathrm{~h}$ at $105{ }^{\circ} \mathrm{C}$. Then, it was baked at $600{ }^{\circ} \mathrm{C}$ in the electric furnace for about $4 \mathrm{~h}$ to calculate the organic matter content by subtracting the ash content from the dry weight. The organic matter content was divided by 1.724 to obtain the organic carbon content (Black 1965). The soil was collected at $10 \mathrm{~cm}$ intervals by using a core soil sampler (diameter = $5 \mathrm{~cm}$, length $=10 \mathrm{~cm}$ ) to measure the bulk density. The collected soil was weighed after drying it in the dryer at $105{ }^{\circ} \mathrm{C}$ until it reached constant weight. And the value was divided by the volume to calculate the bulk density. The bulk density and gravel content ratio was multiplied to the organic carbon content for each soil depth to calculate the amount of organic carbon per unit area by depth (ton $\mathrm{C} \mathrm{ha}^{-1} 20 \mathrm{~cm}$ depth $^{-1}$ ) (Wang et al. 2002).

$$
\begin{aligned}
& \operatorname{SOC}\left(\text { ton ha }{ }^{-1}\right)=\text { Bulk density }\left(\mathrm{g} \mathrm{cm}^{-3}\right) \\
& \times \text { Organic carbon content }\left(\mathrm{g} \mathrm{kg}^{-1}\right) \\
& \times \text { Soil depth }(\mathrm{m}) \\
& \times(1-\text { Gravel content ratio })
\end{aligned}
$$

\section{Soil respiration}

The soil respiration was measured using the closed chamber method with a $\mathrm{CO}_{2}$ gas analyzer (IRGA; EGM-4 PP 
System, UK). The soil respiration was measured at 10 random points that have overlapping tree crowns to minimize the error between measuring points. In this calculation, the maximum and the minimum value was excluded in calculating the average. The soil temperature at $5 \mathrm{~cm}$ depth was automatically monitored hourly with a digital data thermometer (Thermo recorder TR-71UT\&D Co., Japan) installed within the study site to examine the correlation between the soil respiration and the soil temperature. The regression equation was derived and soil respiration was calculated by performing regression analysis on the measured soil respiration and soil temperature.

According to existing studies, the contribution of root respiration towards the soil respiration was $49 \%$ in the Pinus densiflora forest (Nakane et al. 1983), 51\% in the Quercus serrata forest (Nakane et al. 1996), $46 \%$ in the Pinus koraiensis plantation (Pyo et al. 2003), 31\% in the Quercus dominant forest (Lee et al. 2010), and 34\% in the Quercus acutissima forest (Lee et al. 2012). In this study, the root respiration was estimated at $45 \%$ of the soil respiration based on the study of Wang et al. (2012) who reported that the contribution of heterotrophic respiration towards the soil respiration of Q. glauca was 55\%.

\section{Ecosystem valuation}

Assuming the worldwide emission trading scheme is in place, the market price of carbon credit has been reported ranged \$13 80 (OECD 1998). The excess emission penalty for defaulte the greenhouse gas emission trading scheme is $€ 100$ per ton of $\mathrm{CO}_{2}$ in EU, \$6 in Denmark, $£ 30$ in UK (Ministry of environment 2004). In 2013, Korea enacted "Act on The Allocation and Trading of Greenhouse Gas Emission Permits" which includes Chapter 6 Article 33 Penalty Surcharges. It states that if emission permits surrendered by a business entity eligible for allocation are less than greenhouse gas emissions certified, the competent authority may impose a penalty surcharge within the maximum 100,000 won per ton of $\mathrm{CO}_{2}$ for the shortfall. Thus, in alignment with the local law, 100,000 won per ton of $\mathrm{CO}_{2}$ was used to calculate the value of organic carbon in the Q. glauca forest.

\section{Results and discussions}

\section{Organic carbon distribution in plants}

The biomass and organic carbon distribution of the $Q$. glauca forest were 345.85 and 155.63 ton $\mathrm{C} \mathrm{ha}^{-1}$ in 2011, 368.43 and 165.79 ton $\mathrm{C} \mathrm{ha}{ }^{-1}$ in 2012. The average was 357.14 ton $\mathrm{ha}^{-1}$ in 2011 and 160 . 71 ton $\mathrm{C} \mathrm{ha} \mathrm{ha}^{-1}$ in 2012 respectively over the study period. The net primary production of organic carbon over the study period was 14.22 ton $\mathrm{C} \mathrm{ha}^{-1}$ year $^{-1}$. The organic carbon distribution per organs were in following descending order: $46.82 \%$ for stem $\left(75.25\right.$ ton $\left.\mathrm{C} \mathrm{ha}{ }^{-1}\right)$, $31.24 \%$ for branch (50.21 ton $\mathrm{C} \mathrm{ha}^{-1}$ ), 20.00\% for root
(32.15 ton $\mathrm{C} \mathrm{ha}{ }^{-1}$ ), and $1.94 \%$ for leaf and rep. organ (3. 11 ton $\mathrm{C} \mathrm{ha}^{-1}$ ) (Table 1 ).

The biomass of the Q. glauca forest was more than to deciduous broad-leaved forest, such as which is 103. 47 ton $\mathrm{ha}^{-1}$ of Q. acutissima forest in Gongju (Kang 2010) and 161.26 ton $\mathrm{ha}^{-1}$ of Q. variabilis forest in Mt. Worak (Namgung 2010) and 164.00 ton $\mathrm{ha}^{-1}$ of $Q$. acutissima forest, 158.90 ton $\mathrm{ha}^{-1}$ of Q. variabilis forest, 115.30 ton ha $\mathrm{ha}^{-1}$ of Q. seratta forest, 118.80 ton ha $^{-1}$ of $Q$. mongolica forest in Mt. Mohu (Park and Moon 1994). And it was more than double the average biomass of $Q$. glauca plantation in Goseong-gun, which is 145.5 ton ha ${ }^{-}$ ${ }^{1}$ (Choi et al. 2016). Moreover, the carbon stocks of the $Q$. glauca forest was greater than that of deciduous broadleaved forest and evergreen broad-leaved forest in warmtemperate region, such as 325.6 ton $\mathrm{ha}^{-1}$ in Quercus acuta forest (Lee et al. 2007) and 123.7 ton $\mathrm{ha}^{-1}$ in Machilus thunbergii forest (Lee and Kim 1988), respectively. The net primary production of the Q. glauca forest was more than to deciduous broad-leaved forest, such as which is 99. 69 ton $\mathrm{C} \mathrm{ha}{ }^{-1}$ of Q. mongolica forest in Mt. Worak (Won et al. 2014) and 86.02 ton $C$ ha $^{-1}$ of $Q$. mongolica forest, 46. 10 ton $\mathrm{C} \mathrm{ha}{ }^{-1}$ of Robinia pseudoacacia forest in $\mathrm{Mt}$. Nam (Lee 2011) and 72.57 ton $C$ ha $^{-1}$ of Q. variabilis forest in Mt. Worak (Namgung 2010). Based on the study conducted in the experimental Q. glauca forest managed by governmental research center, Son et al. (2014) reported organic carbon distribution and NPP as 278.91 ton $\mathrm{C} \mathrm{ha}^{-1}$ and 12.29 ton $\mathrm{C} \mathrm{ha}^{-1}$ year $^{-1}$ respectively. In comparison, the organic carbon distribution of the study site was lower but NPP was higher than the reported figure. It figured that such differences are caused by tree density, tree age, region, altitude, locational conditions, as well as climate, which could have affected the growth and production even within the same species.

\section{Amount of organic carbon flowing into the forest floor through litter production}

The litter production of Q. glauca forest continued throughout the year. The amount of organic carbon flowing into the forest floor through litter production

Table 1 Biomass (ton ha-1), organic carbon (ton $\mathrm{Cha}^{-1}$ ), and NPP (ton C ha ${ }^{-1}$ year $^{-1}$ ) at the Q. glauca forest in the study area

\begin{tabular}{|c|c|c|c|c|c|}
\hline \multirow[t]{2}{*}{ Component } & \multicolumn{2}{|c|}{ Biomass } & \multicolumn{2}{|c|}{ Organic carbon } & \multirow[t]{2}{*}{ NPP } \\
\hline & 2011 & 2012 & 2011 & 2012 & \\
\hline $\begin{array}{l}\text { Leaf+ } \\
\text { Rep. organ }\end{array}$ & 7.61 & 6.20 & 3.43 & 2.79 & 3.43 \\
\hline Branch & 107.27 & 115.90 & 48.27 & 52.16 & 3.89 \\
\hline Stem & 161.80 & 172.64 & 72.81 & 77.69 & 4.88 \\
\hline Root & 69.17 & 73.69 & 31.13 & 33.16 & 2.03 \\
\hline Total & 345.85 & 368.43 & 155.63 & 165.79 & 14.22 \\
\hline
\end{tabular}

Rep. organ, reproductive organ 
was 3.39 ton $\mathrm{C} \mathrm{ha}{ }^{-1}$ year $^{-1}$ in 2011 and 3.45 ton $\mathrm{C}$ ha ${ }^{1}$ year $^{-1}$ in 2012, averaging at 3.42 ton $C$ ha $^{-1}$ year ${ }^{-1}$. The organic carbon distribution for the organs were in following descending order: $68.41 \%$ for leaves (2. 34 ton $\mathrm{C} \mathrm{ha}$ hear $\left.^{-1}\right), 15.92 \%$ for branch and bark ( 0 . 54 ton $\mathrm{C} \mathrm{ha} \mathrm{ha}^{-1}$ year $\left.^{-1}\right), 11.96 \%$ for rep. organ (0. 41 ton $\mathrm{C} \mathrm{ha}$ year $^{-1}$ ), and $3.71 \%$ for misc. (0. 13 ton $\mathrm{C} \mathrm{ha}^{-1}$ year $^{-1}$ ) (Fig. 1).

The litter production did not show particular change in pattern with change in seasons. It is probably because the leaf cycle of the Q. glauca forest is different from that of deciduous trees which mostly shed their leaves in fall. In 2012, the litter production of the Q. glauca forest was similar to that of deciduous trees in fall but this was likely caused by the typhoon; no typhoons landed in 2011 but typhoon 'Bolaven' landed in 2012 (Jang et al. 2014).

The amount of organic carbon flowing into the forest floor through the litter production of Q. glauca forest was similar to the amount in high density stands of $Q$. glauca forest in Goseong-gun (Choi et al. 2016) which was 3.56 ton $\mathrm{C} \mathrm{ha}{ }^{-1}$ year $^{-1}$ but it was higher than low density stands by 2.25 ton $\mathrm{C} \mathrm{ha}^{-1}$ year $^{-1}$. In addition, it was lower than 5.22 ton $\mathrm{C}$ ha $^{-1}$ year $^{-1}$ of Machilus thunbergii forest in Wando-gun (Lee and Kim 1988). The difference is likely due to litter production and environmental factors, such as tree species, climate, altitude, stand density, and DBH of the study site.
Amount of organic carbon in the forest floor litter

The amount of organic carbon in the forest floor litter was $3.61 \pm 0.74$ ton $C$ ha $^{-1}$ in 2011 and $6.39 \pm 0$. 09 ton $\mathrm{C} \mathrm{ha}^{-1}$ in 2012, averaging at $5.00 \pm 0.62$ ton $\mathrm{C} \mathrm{ha}^{-1}$ over the study period. The average amount of organic carbon of L-layer was $2.27 \pm 2.01$ ton $\mathrm{C} \mathrm{ha}^{-1}$ and F-layer was $2.73 \pm 1.28$ ton $\mathrm{C}$ ha $^{-1}$. The amount in F-layer was greater than that of L-layer by 0.46 ton $\mathrm{C} \mathrm{ha}^{-1}$ on average (Table 2). The amount of organic carbon in the forest floor litter did not show any notable change in pattern and it was generally consistent with the litter production. This consistency is attributable to the balance between the rate at which the litter fall and the rate of decomposition in the forest floor litter (Waring and Schlesinger 1987).

The amount of organic carbon in the forest floor litter of the Q. glauca forest was similar to $5.02 \pm 0.48$ ton $\mathrm{C} \mathrm{ha}{ }^{-}$ 1 of Quercus variabilis forest (Namgung 2010) and $4.71 \pm 1$. 02 ton $\mathrm{C}$ ha- 1 of Pinus densiflora forest in Mt. Worak (Lee et al. 2013), as well as $4.89 \pm 0.63$ ton $\mathrm{C} \mathrm{ha}^{-1}$ of Quercus mongolica forest in Mt. Geumgang (Won et al. 2016). On the other hand, it was lower than $6.31 \pm 0$. 55 ton $\mathrm{C} \mathrm{ha}{ }^{-1}$ of Quercus mongolica forest in Mt. Worak and $6.02 \pm 1.29$ ton $\mathrm{C} \mathrm{ha}^{-1}$ of Pinus densiflora forest in Mt. Geumgang (Won et al. 2016). This difference among sites or forests is caused by the rate of litter production and decomposition, and environmental factors, such as temperature and rainfall.

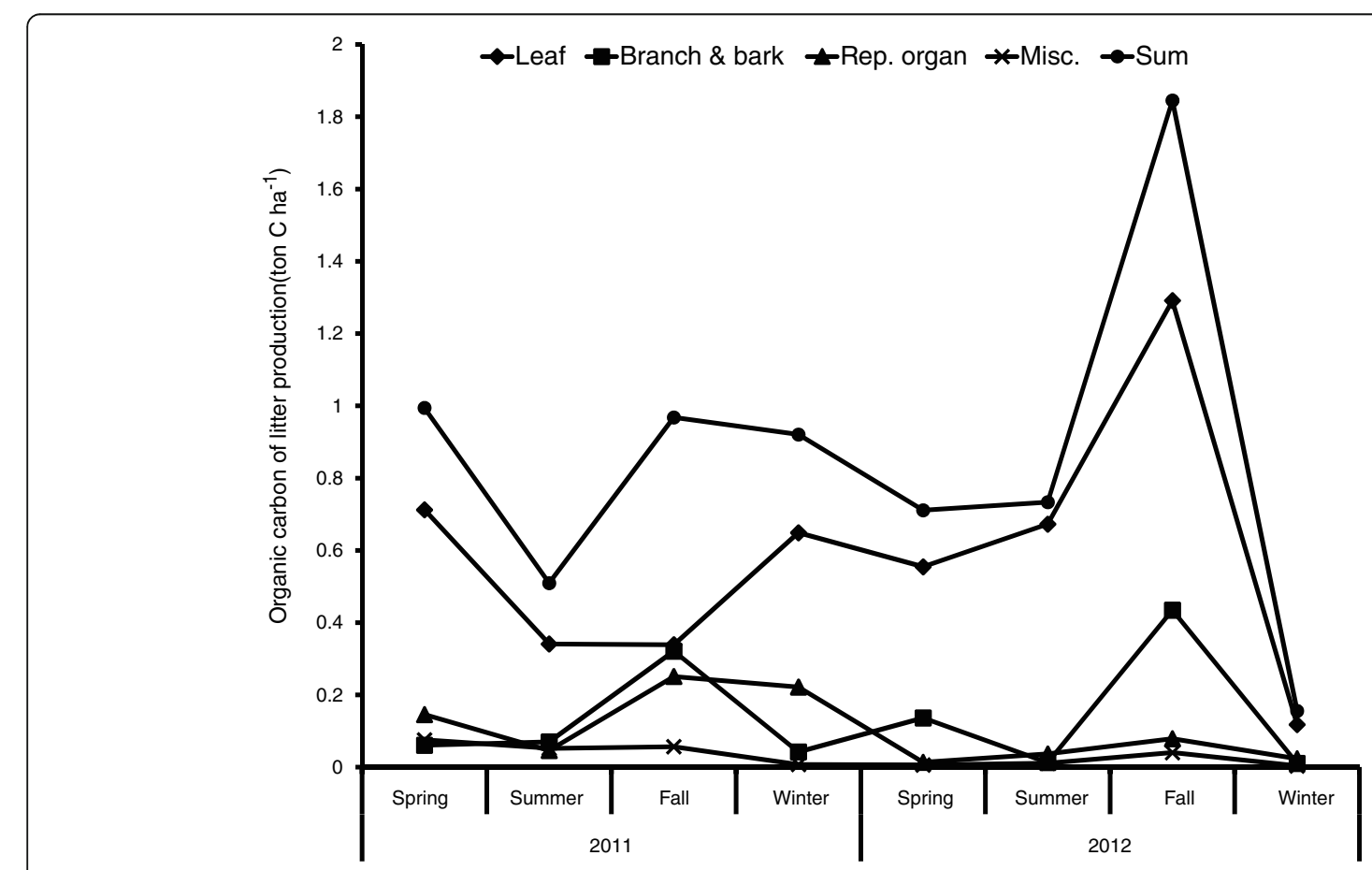

Fig. 1 Seasonal organic carbon of litter production (ton $C \mathrm{ha}^{-1}$ ) at the Q. glauca forest in the study area. Misc.: Miscellaneous 
Table 2 Seasonal organic carbon on the forest floor (ton $\mathrm{C} \mathrm{ha}{ }^{-1}$ ) at the $Q$. glauca forest (mean \pm SD) in the study area

\begin{tabular}{lllll}
\hline Year & Season & \multicolumn{3}{l}{ Layer } \\
\cline { 3 - 5 } & & L & F & Total \\
\hline 2011 & Spring & $1.10 \pm 0.87$ & $1.92 \pm 1.40$ & $3.03 \pm 0.58$ \\
& Summer & $2.02 \pm 1.48$ & $2.54 \pm 1.05$ & $4.55 \pm 0.37$ \\
& Fall & $1.04 \pm 0.72$ & $2.89 \pm 1.53$ & $3.93 \pm 1.30$ \\
& Winter & $0.98 \pm 0.87$ & $1.96 \pm 0.99$ & $2.94 \pm 0.69$ \\
& Sub-mean & $1.29 \pm 0.49$ & $2.33 \pm 0.47$ & $3.61 \pm 0.74$ \\
2012 & Spring & $1.32 \pm 0.53$ & $1.85 \pm 0.87$ & $3.17 \pm 0.38$ \\
& Summer & $3.25 \pm 2.60$ & $2.73 \pm 1.75$ & $5.98 \pm 0.37$ \\
& Fall & $6.89 \pm 1.64$ & $5.74 \pm 2.43$ & $12.63 \pm 0.81$ \\
& Winter & $1.60 \pm 0.45$ & $2.20 \pm 0.22$ & $3.80 \pm 0.43$ \\
& Sub-mean & $3.26 \pm 2.56$ & $3.13 \pm 1.78$ & $6.39 \pm 0.09$ \\
Mean & & $2.27 \pm 2.01$ & $2.73 \pm 1.28$ & $5.00 \pm 0.62$ \\
\hline
\end{tabular}

\section{Organic carbon distribution in soil}

The bulk density of soil was $0.43 \mathrm{~g} \mathrm{~cm}^{-3}$ at $10 \mathrm{~cm}$ depth and $0.49 \mathrm{~g} \mathrm{~cm}^{-3}$ at $20 \mathrm{~cm}$ depth. The average amount of organic carbon in $20 \mathrm{~cm}$ soil depth was $9.80 \pm 4$. 14 ton $\mathrm{C} \mathrm{ha}^{-1}$ (Fig. 2).

By layer, the average amount of organic carbon was 47 . $83 \pm 9.43$ ton $\mathrm{C} \mathrm{ha}^{-1}$ at $10 \mathrm{~cm}$ depth and $41.97 \pm 14$. 00 ton $\mathrm{C} \mathrm{ha}^{-1}$ at $20 \mathrm{~cm}$ depth, showing higher amount in the upper layer $(10 \mathrm{~cm})$ than the lower layer $(20 \mathrm{~cm})$. It is generally known that the amount of organic carbon in soil decreases exponentially with greater depth (Eswaran et al. 1995), and this is primarily related to the amount of organic matter flowing into the forest floor litter.

The annual average amount of organic carbon was 78 . $89 \pm 6.84$ ton $\mathrm{C} \mathrm{ha}^{-1}$ in 2011 and $100.71 \pm 1.45$ ton $\mathrm{C} \mathrm{ha}{ }^{-1}$ in 2012. The figure was higher in 2012 than in 2011 because of the effect of typhoon in 2012: more organic matter, such as leaves, branches, and barks, fell on the top soil from aboveground and decomposed (Armson 1977).

The seasonal average amount of organic carbon were in following descending order: $109.35 \pm 47.80$ ton $^{C}$ ha $^{-1}$ in winter, $89.74 \pm 5.11$ ton $\mathrm{C} \mathrm{ha}^{-1}$ in spring, $85.41 \pm 2$. 93 ton $\mathrm{C} \mathrm{ha}{ }^{-1}$ in summer, and $74.70 \pm 11.73$ ton $\mathrm{C}$ ha ${ }^{-1}$ in fall. The organic carbon in soil is decomposed by microarthropods and soil microbials (Gill 1969). The activity of microarthropods and soil microbials is largely affected by the temperature and it seems that this is the main reason for the high figure in the amount of organic carbon in winter when their activity was low. Also, the seasonal amount of organic carbon in soil showed similar trends to the litter production. Even though it takes some time for leaves to decompose and to release organic carbon into the soil, it is known that water soluble matter leaches fast in the early stage of decomposition. And it is known that the decomposition of leaves of Quercus myrsinaefolia, an evergreen tree, is faster than that of Quercus acutissima, a deciduous tree (Won et al. 2012). Therefore, the organic carbon in soil is greatly affected by the litter production, supporting

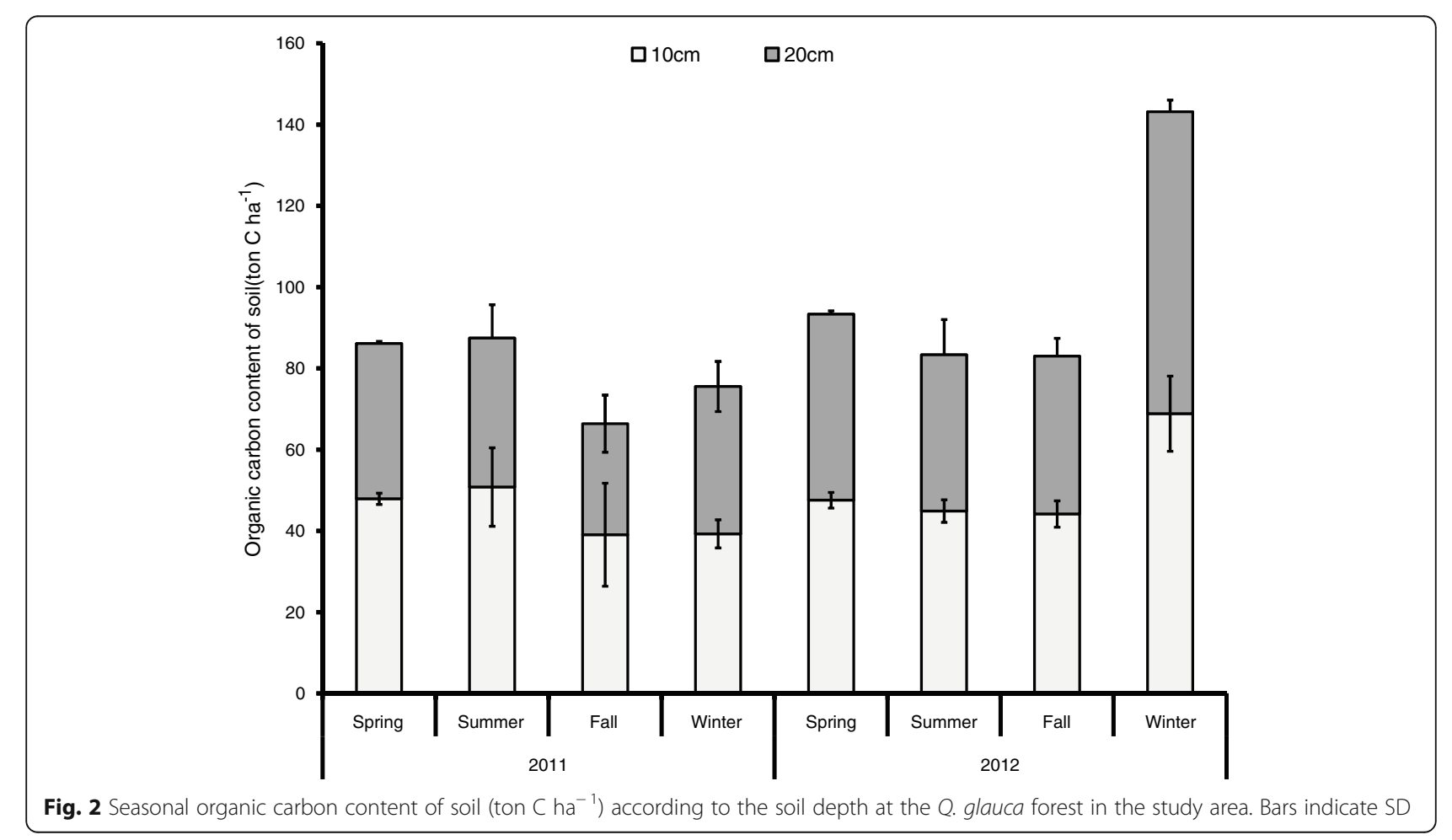


the idea that the organic matter in leaves is directly related to the organic carbon in soil. And it seems that the differences in amounts each season are caused by the time it takes for organic carbon in the top soil to get decomposed.

\section{Amount of soil respiration}

The average amount of soil respiration was $0.64 \mathrm{~g} \mathrm{CO}_{2} \mathrm{~m}^{-}$ ${ }^{2} \mathrm{~h}^{-1}$ in 2011 and $0.59 \mathrm{~g} \mathrm{CO}_{2} \mathrm{~m}^{-2} \mathrm{~h}^{-1}$ in 2012. The seasonal average soil respiration were in following descending order: $0.73 \mathrm{~g} \mathrm{CO}_{2} \mathrm{~m}^{-2} \mathrm{~h}^{-1}$ in summer, 0 . $38 \mathrm{~g} \mathrm{CO}_{2} \mathrm{~m}^{-2} \mathrm{~h}^{-1}$ in fall, $0.17 \mathrm{~g} \mathrm{CO}_{2} \mathrm{~m}^{-2} \mathrm{~h}^{-1}$ in spring, and $0.07 \mathrm{~g} \mathrm{CO}_{2} \mathrm{~m}^{-2} \mathrm{~h}^{-1}$ in winter. The trend showed an increasing amount of soil respiration from the winter season to the summer season (Fig. 3). Such trend is likely attributable to the increased amount of $\mathrm{CO}_{2}$ emitted through greater heterotrophic and root respiration caused by higher soil temperature. It is already known that soil temperature, moisture, and organic matter content are the main factors that affect soil respiration (Llody and Taylor 1994; Raich and Potter 1995).

The forest soil respiration is the sum of heterotrophic respiration and root respiration (Hanson et al. 2000). It is necessary to increase the accuracy of the estimate for heterotrophic respiration and root respiration to derive at net ecosystem production (NEP) because NEP of forest ecosystems is determined by NPP and heterotrophic respiration (Lee et al. 2003). However, there was a difficulty in measuring the heterotrophic respiration due to location condition and experimental method. Therefore, the reported heterotrophic respiration of the same species was used to estimate the root respiration at $45 \%$ of the amounts of soil respiration (Wang et al. 2012). The amount of soil respiration emitted into the atmosphere through soil respiration was 16.77 ton $\mathrm{C} \mathrm{ha}{ }^{-1}$ year ${ }^{-1}$ in 2011 and 14.44 ton $\mathrm{C} \mathrm{ha}^{-1}$ year $^{-1}$ in 2012. The amount of organic carbon released through heterotrophic respiration was 9.22 ton $\mathrm{C} \mathrm{ha}^{-1}$ year $^{-1}$ in 2011 and 7.94 ton $\mathrm{C}$ ha $^{-}$ ${ }^{1}$ year $^{-1}$ in 2012 . The amount of organic carbon released through root respiration was estimated at 7.54 ton $\mathrm{C}^{-}{ }^{-}$ ${ }^{1}$ year $^{-1}$ in 2011 and 6.50 ton $\mathrm{C}$ ha $^{-1}$ year $^{-1}$ in 2012.

\section{Ecosystem valuation through organic carbon distribution and cycling}

The organic carbon distribution and cycling of the $Q$. glauca forest for each carbon storage are summarized in Fig. 4. The amount of organic carbon distribution was 124 . 5 ton $\mathrm{C} \mathrm{ha} \mathrm{h}^{-1}$ in 2011 and 132.63 ton $\mathrm{C} \mathrm{ha}{ }^{-1}$ in 2012 for aboveground biomass. And it was 31.13 ton $\mathrm{C} \mathrm{ha}^{-1}$ in 2011 and 33.16 ton $\mathrm{Cha}^{-1}$ in 2012 for belowground biomass. In total, the amount of organic carbon distribution in plants was 155.63 and 165.79 ton $C$ ha $^{-1}$ in 2011 and 2012, respectively. In 2011 and 2012, respectively, the amount of organic carbon distribution was 3.61 and 6.39 ton $\mathrm{C} \mathrm{ha}^{-1}$ in the forest floor and it was 78.89 and 100.71 ton $\mathrm{C} \mathrm{ha}^{-1}$ in the soil. As shown, the most carbon was distributed in plants. Overall, the amount of organic carbon distribution

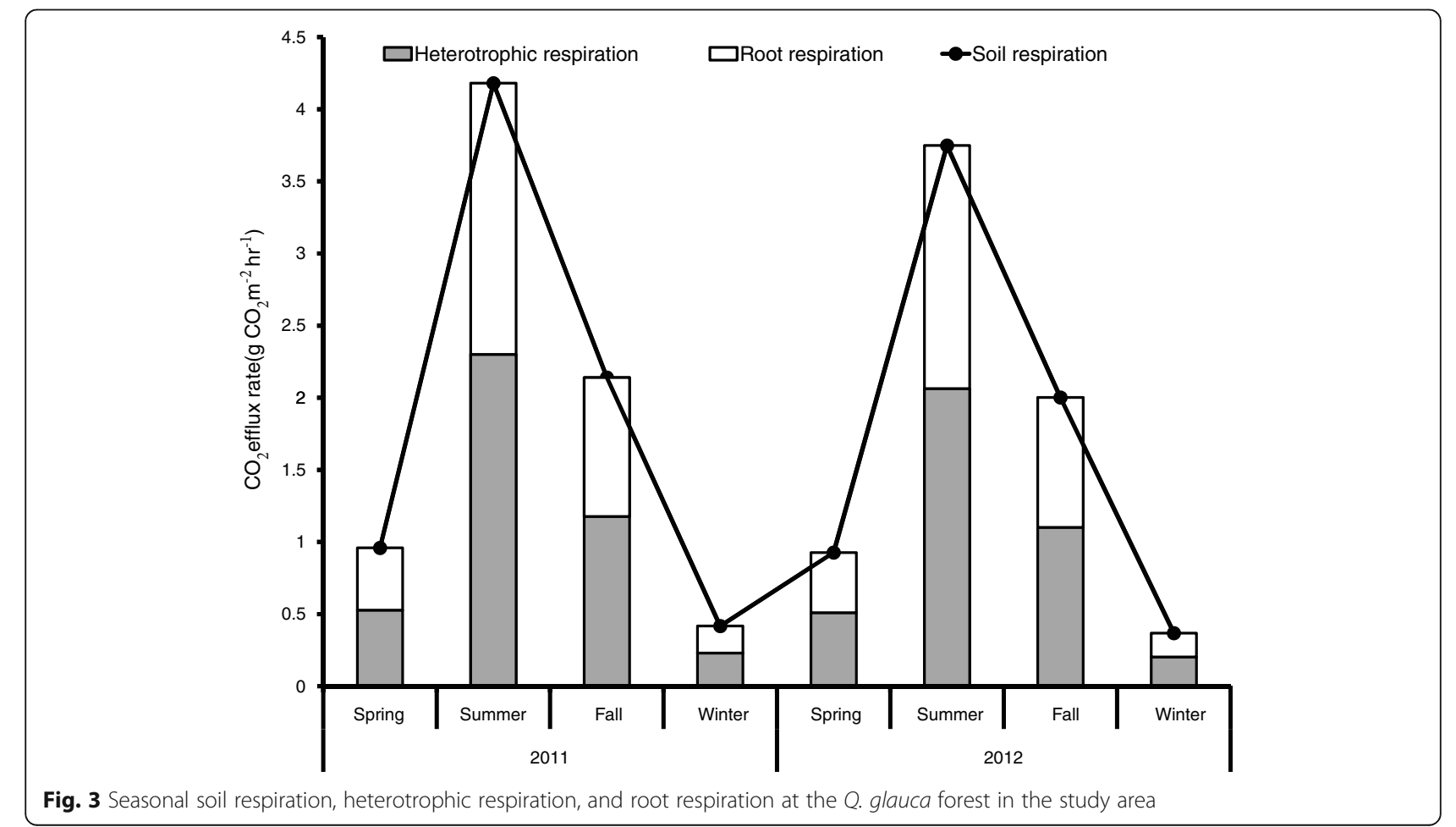




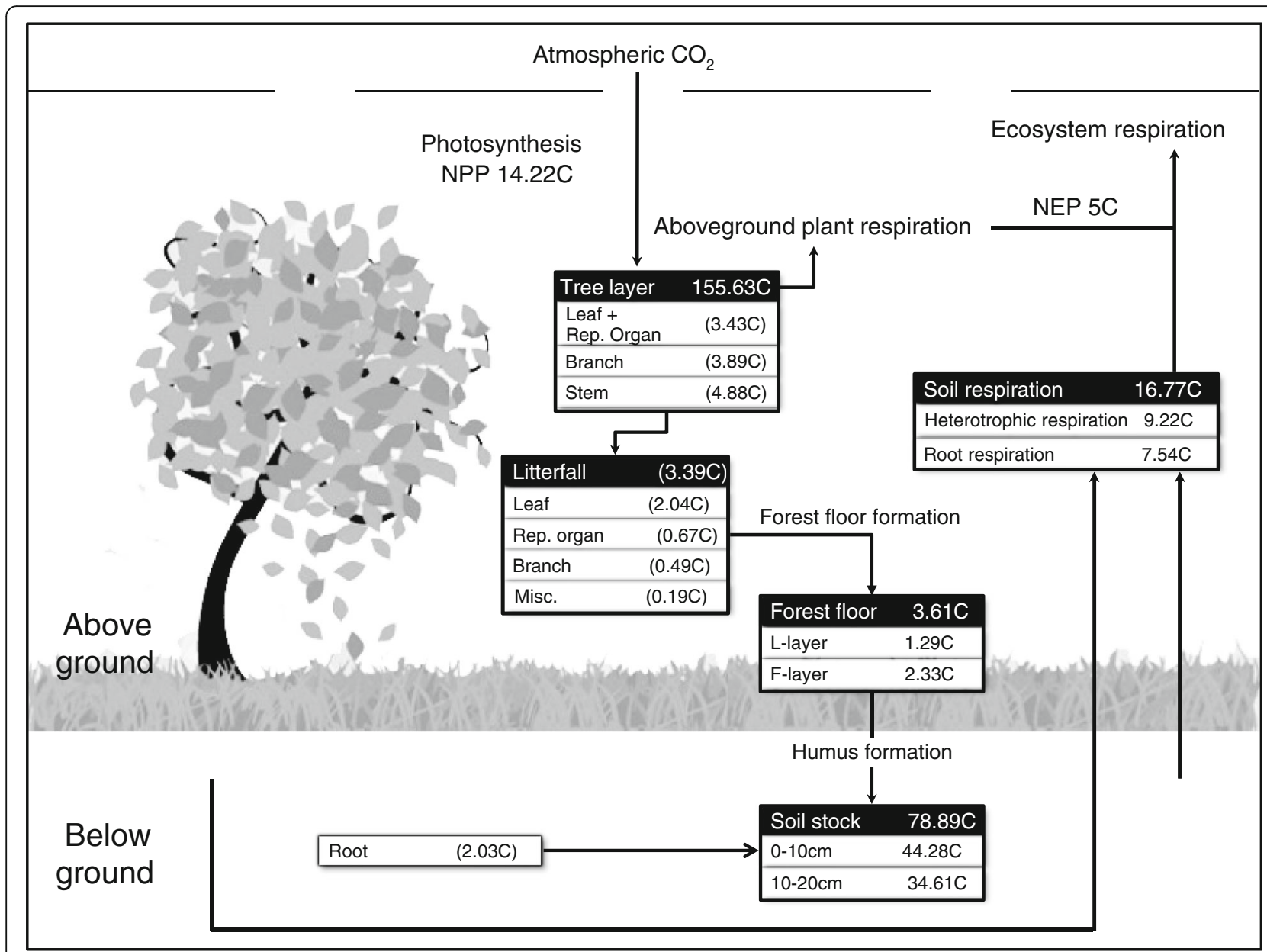

Fig. 4 Compartment model showing the distribution and flow of organic carbon at the Q. glauca forest for 2011 in the study area. Box: standing carbon (ton $\mathrm{C} \mathrm{ha}^{-1}$ ), arrow: flux (ton $\mathrm{C} \mathrm{ha} \mathrm{a}^{-1} \mathrm{year}^{-1}$ ). Parenthesis indicate NPP (ton C ha ${ }^{-1}$ year ${ }^{-1}$ )

of the Q. glauca forest was 238.13 ton $\mathrm{C} \mathrm{ha}^{-1}$ in 2011 and 272.89 ton $\mathrm{C} \mathrm{ha}^{-1}$ in 2012.

In 2011, the amount of organic carbon fixed in plants through photosynthesis was 14.22 ton $\mathrm{C} \mathrm{ha}^{-1}$ year $^{-1}$ and the amount emitted through soil respiration was 16. 77 ton $\mathrm{C}$ ha $^{-1}$ year $^{-1}$ which can be further classified into heterotrophic respiration and root respiration of 9.22 and 7.54 ton $\mathrm{C} \mathrm{ha}^{-1}$ year $^{-1}$, respectively. NEP of the Q. glauca forest was 5 ton $\mathrm{C}$ ha $^{-1}$ year $^{-1}$ based on the difference between organic carbon net primary production of 14 . 22 ton $\mathrm{C} \mathrm{ha}^{-1}$ year $^{-1}$ and heterotrophic respiration of 9 . 22 ton $\mathrm{C} \mathrm{ha}{ }^{-1}$ year $^{-1}$. Therefore, the Q. glauca forest acted as a positive (+) factor in improving the atmospheric environment by absorbing more atmospheric $\mathrm{CO}_{2}$ than it released fulfilling its role as a carbon sinks.

The Q. glauca forest in this study displayed greater amount of organic carbon absorption than any other forests acting as carbon sinks, such as 4.60 ton $\mathrm{C} \mathrm{ha}{ }^{-1}$ year $^{-1}$ of Q. acutissima forest in Gongju-si (Lee and Mun 2005), 1.03 ton $\mathrm{C} \mathrm{ha}{ }^{-1}$ year $^{-1}$ of $Q$. variabilis forest in Mt.
Worak (Namgung 2010), 1.50 ton $\mathrm{C} \mathrm{ha}^{-1}$ year $^{-1}$ of $Q$. mongolica forest in Mt. Worak (Shin 2012), 0. 44 ton $\mathrm{C} \mathrm{ha}^{-1}$ year $^{-1}$ of $P$. densiflora forest in Mt. Worak (Won et al. 2015), and 3.90 ton $C$ ha $^{-1}$ year $^{-1}$ of $Q$. mongolica forest and 0.81 ton $\mathrm{C} \mathrm{ha}$ hear $^{-1}$ of $P$. densiflora forest in Mt. Geumgang (Won et al. 2016).

The carbon absorption value of Q. glauca forest was estimated about 500,000 won $\mathrm{ha}^{-1}$ applying the penalty surcharge per ton of $\mathrm{CO}_{2}$ stated in "Act on The Allocation and Trading of Greenhouse Gas Emission Permits." Its carbon storage value was estimated about 23. 81 mil won ha ${ }^{-1}$ in 2011 and 27.29 mil won ha $^{-1}$ in 2012.

This study was conducted to value the ecosystem of the Q. glauca forest through organic carbon distribution and cycling. The existing carbon stocks valuations employ models and remote sensing analysis to obtain results, but such methods underestimates the value and is less accurate than the field study (Oh et al. 2015). This study more accurately estimated the value of the ecosystem through the field study method. In addition, the 
value of carbon absorption and storage function, which are part of forest ecosystem services, were calculated. Thus, the value of an ecosystem will greatly increase if integrated ecosystem valuation were to be performed on various services, such as soil retention, soil formation, gas regulation, water regulation, water and wood supply, biological control, recreation, habitat, and biodiversity.

\section{Conclusions}

As a major carbon sink, the Q. glauca forest in this study displayed greater amount of organic carbon distribution and absorption than those of previously reported forests. Therefore, the distribution range expansion of $Q$. glauca forest due to climate change will be effective for carbon sequestration. In conclusion, the study results could be used as a primary data to establish land-use planning that enhances carbon storage and absorption.

\section{Abbreviations}

DBH: Diameter at breast height; F: Fermentation; H: Height; L: Litter; MA: Millennium Ecosystem Assessment; NEP: Net ecosystem production; NPP: Net primary production; SOC: Soil organic carbon; UNFCCC: United Nations Framework Convention on Climate Change

\section{Acknowledgements}

Following are results of a study on the "National Long-term Ecological Research" Project of the Ministry of Environment.

\section{Funding}

This work (Grant No. C056473) was supported by Business for Cooperative R\&D between Industry, Academy, and Research Institute funded Korea Small and Medium Business Administration in 2017.

\section{Authors' contributions}

All authors conducted a survey together during the study period. HYS wrote the manuscript. YYH participated in the design of the study and examined the manuscript. All authors read and approved the final manuscript.

Ethics approval and consent to participate

Not applicable.

\section{Competing interests}

The authors declare that they have no competing interests.

\section{Publisher's Note}

Springer Nature remains neutral with regard to jurisdictional claims in published maps and institutional affiliations.

\section{Author details}

${ }^{1}$ Division of Ecological Survey Research, National Institute of Ecology, Seocheon, Republic of South Korea. ${ }^{2}$ Department of Biology, Kongju National University, Kongju, Republic of South Korea.

Received: 30 November 2017 Accepted: 27 April 2018

Published online: 24 May 2018

\section{References}

Armson, K. A. (1977). Forest soils: properties and processes. Canada: University of Toronto Press.

Black, C. A. (1965). Methods of soil analysis, part 2. chemical and microbiological properties. Madison: Inc.

Boumans, R., Costanza, R., Farley, J., Wolson, M. A., Portela, R., Rotmans, J., Villa, F., \& Grasson, M. (2002). Modeling the dynamics of the integrated earth system and the value of global ecosystem services using the GUMBO model. Ecological Economic, 41, 529-560.
Brander, L. M., Wagtendonk, A. J., Hyssain, S. S., McVittie, A., Verburg, P. H., de Groot, R. S., \& van der Ploeg, S. (2012). Ecosystem service values for mangroves in Southeast Asia: a meta-analysis and value transfer application. Ecosystem Services, 1, 62-69.

Choi, B. J., Baek, G., Jo, C. G., Park, S. W., Yoo, B. O., Jeong, S. Y., Lee, K. S., \& Kim, C. (2016). Biomass and nutrient stocks of tree components by stand density in a Quercus glauca plantation. Journal of Korean Forest Society, 105(3), 294-302.

Eswaran, H., Van den Berg, E., Reich, P., \& Kimble, J. (1995). Global soil carbon resources. In R. Lal, J. Kimble, E. Levine, \& B. A. Stewart (Eds.), Soils and global change (pp. 27-44). Boca Raton: CRC-Press.

Gill, R. W. (1969). Soil microarthropod abundance following old-field litter manipulation. Ecology, 50, 805-816.

Gitay, H., Brown, S., Easterling, W., \& Jallow, B. (2001). Ecosystems and their goods and services. In J. J. McCarthy, O. F. Canziani, N. A. Leary, D. J. Dokken, \& K. S. White (Eds.), Climate change 2001: impacts, adaptation and vulnerability. Contribution of working group II to the third assessment report of the IGBP on climate change. New York: Cambridge University Press.

Han, B. H., Kim, J. Y., Choi, I. T., \& Lee, K. J. (2007). Vegetation structure of evergreen broad-leaved forest in Dongbaekdongsan(Mt.), Jeju-Do, Korea. Korean Journal of Environment and Ecology, 21(4), 336-346.

Han, D. Y. (2002). Carbon cycling modelling by litter decomposition rate and estimation of carbon dioxide budget in Quercus mongolica forest at Mt. Songni National Park. Ph.D. dissertation. Korea: Chungbuk National University.

Han, Y. S. (2014). A study on carbon distribution and budget of dominant plant community in Gotjawal, Jeju Island. M.S. thesis. Korea: Kongju National University.

Hanson, P. J., Edwards, N. T., Garten, C. T., \& Andrews, J. A. (2000). Separation root and soil microbial contributions to soil respiration: A review of methods and observation. Biogeochemistry, 48, 115-146.

Houghton, R. A., Hobbie, J. E., Melillo, J. M., Moore, B., Peterson, B. J., Shaver, G. R., \& Woodwell, G. M. (1983). Changes in the carbon content of terrestrial biota and soils between 1860 and 1980: a net release of $\mathrm{CO}_{2}$ to the atmosphere. Ecological Monographs, 53, 235-262.

IPCC. (2013). Climate change 2013: the physical science basis. Working Group I Contribution to the Fifth Assessment Report of the Intergovernmental Panel on Climate Change. New York: Cambridge university press.

Jang, R. H., Cho, K. T., \& You, Y. H. (2014). Annual biomass production and amount of organic carbon in Abis koreana forest of subalpine zone at Mt. Halla. Korean Journal of Environment and Ecology, 28(6), 627-633.

Jeong, H. M., Kim, H. R., Cho, K. T., Lee, S. H., Han, Y. S., \& You, Y. H. (2014). Aboveground biomass estimation of Quercus glauca in evergreen forest, Kotzawal wetland, Cheju Island, Korea. Journal of Wetlands Research, 16(2), 245-250.

Jeong, H. M., Kim, H. R., \& You, Y. H. (2013). A study on the ecosystem services of wetland 1. Effective biological control of the mosquito larvae using native fishes. Journal of Wetlands Research, 15(1), 19-24.

Jin, F., Yang, H., \& Zhao, Q. (2000). Progress in the research of organic carbon storage. The Soil, 32(1), 11-17.

Johnson, F. L., \& Risser, P. G. (1974). Biomass, annual net primary production and dynamics of six mineral elements in a post oak-blackjack oak forest. Ecology, $55,1246-1258$

Kang, K. N. (2010). A study on carbon storage in aboveground, root, and fine root of major afforestation species of Korea-a case study of Pinus densiflora, Pinus koraiensis, Larix leptolepis and Quercus acutissima stands Gongju area, Chungnam Province.-. Ph.D. Disseration. Korea: Chungnam National University.

Kang, S. J., \& Kwak, A. K. (1998). Comparisons of phytomass and productivity of watershed forest by allometry in South Han River. Journal of Korea Forestry Energy Research Society, 17(1), 8-12.

Kawk, J. I., Lee, K. J., Han, B. H., Song, J. H., \& Jang, J. S. (2013). A study on the vegetation structure of evergreen broad-leaved forest Dongbaekdongsan(Mt.) in Jeju-do, Korea. Korean Journal of Environment and Ecology, 27(2), 241-252.

Kim, J. H., Kim, R. H., Youn, H. J., Lee, S. W., Choi, H. T., Kim, J. J., Park, C. R., \& Kim, K. D. (2012). Valuation of nonmarket forest resources. The Journal of Korean Institute of Forest Recreation, 16(4), 9-18.

Kim, Y. H. (2015). Estimation of secondary emissions from forest carbon offset projects. Journal of Climate Change Research, 6(4), 257-265.

Koo, M. H., Lee, D. K., \& Jung, T. Y. (2012). A study on the contexts of ecosystem services in the policy making process. Journal of the Korean Society of Environmental Restoration Technology, 15(5), 58-102.

Kremen, C. (2005). Managing ecosystem services: what do we need to know about their ecology? Ecology Letters, 8(5), 468-479. 
Lee, J. S., \& Kim, C. S. (1988). Biomass production of Machilus thunbergii S. Et Z. Stand at Bogil Island in Korea. Journal of Korean Forestry Society, 77(1), 10-16.

Lee, J. Y., Kim, D. K., Won, H. Y., \& Mun, H. T. (2013). Organic carbon distribution budget in the Pinus densiflora Forest at Mt. Worak National Park. Korean Journal of Environment and Ecology, 27(5), 561-570.

Lee, K. J. (2013). Carbon budget and nutrient cycling in the Quercus acutissima forest. Ph.D. Dissertation. Korea: Kongju National University.

Lee, K. J., \& Mun, H. T. (2005). Organic carbon distribution in an oak forest. Journal of Ecology and Environment, 28(5), 265-270.

Lee, K. J., Won, H. Y., \& Mun, H. T. (2012). Contribution of root respiration to soil respiration for Querecus acutissima forest. Korean Journal of Environment and Ecology, 26(5), 780-786.

Lee, M., Nakane, K., Nakatsubo, T., \& Koizumi, H. (2003). Seasonal changes in the contribution of root respiration to total soil respiration in a cool-temperate deciduous forest. Plant and Soil, 255(1), 311-318.

Lee, N. Y., Koo, J. W., Noh, N. J., Kim, J., \& Son, Y. (2010). Autotrophic and heterotrophic respiration in needle fir and Quercus-dominated stands in a cooltemperate forest, Central Korea. Journal of Plant Research, 123(4), 485-495.

Lee, S. K. (2011). Production and litter decomposition and organic carbon distribution in Pinus densiflora and Quercus mongolica and Robinia pseudoacacia forests at Mt. Nam. M.S. Thesis. Korea: Kongju National University.

Lee, S. T., Hwang, J. H., Lee, K. J., Shin, H. C., Kim, B. B., Park, M. S., Jun, K. S., \& Cho, H. S. (2007). Biomass Expansion Factors(BEFs) for Quercus acuta according to age classes. Korean Journal of Environment and Ecology, 21(6), 554-558.

Llody, J., \& Taylor, J. A. (1994). On the temperature dependence of soil respiration. Functional Ecology, 8(3), 315-323.

MA(Millennium Ecosystem Assessment). 2005. Ecosystems and human wellbeing millennium ecosystem assessment island press. Washington DC.

Malmsheimer, R. W., Heffernan, P., Brink, S., Crandall, D., Deneke, F., Galik, C., Gee E., Helms, J. A., McClure, N., Mortimer, M., Ruddell, S., Smith, M., \& Stewart, J. (2008). Forest management solutions for mitigating climate change in the United States. Journal of Forestry, 106(3), 115-173.

Ministry of environment. (2004). A study on implementation plan of greenhouse gas emission trading system in Korea (p. 185). Ministry of environment.

Nakane, K., Kohno, T., \& Horikoshi, T. (1996). Root respiration rate before and just after clear-felling in a mature, deciduous, broad-leaved forest. Ecological Research, 11(2), 111-119.

Nakane, K., Yamamoto, M., \& Tsubota, H. (1983). Estimation of root respiration rate in a mature forest ecosystem. Japanese Journal of Ecology, 33, 397-408.

Namgung, J. (2010). Production and nutrient cycling in Quercus variabilis forest at Mt. Worak. Ph.D. Dissertation. Korea: Kongju National University.

Nelson, E., Mendoza, G., Regetz, J., Polasky, S., Tallis, H., Cameron, D. R., Chan, K. M. A., Daily, G. C., Goldstein, J., Kareiva, P. M., Lonsdorf, E., Naidoo, R., Ricketts, T. H., \& Shaw, M. R. (2009). Modeling multiple ecosystem services, biodiversity conservation, commodity production and tradeoffs at landscape scales. Frontiers in Ecology and the Environment, 7(1), 4-11.

OECD. (1998). Economic modelling of climate change. Workshop Report.

Busan development institute. (2011). Improvement of forest public functions in Busan: application of monetary valuation (pp. 1-77). Busan Development Institute.

Oh, W. S., Choi, S., Kwon, H. S., Lee, Y. K., Jung, P. M., Shin, J. S., Jeon, S. H., Bang, E. J., Kim, B. R., Lee, T. H., Kim, J. I., Park, H. J., Song, H. R., Kim, J. M., \& Choe, J. C. (2015). National ecosystem assessment for the sustainable land management -regulation services-. National Institute of Ecology. Strategy research (pp. 1-221).

Park, I. H., \& Moon, G. S. (1994). Biomass, net production and biomass estimation equations in some natural Quercus forests. Journal of Korean Forest Society., 83(2), 246-253

Pyo, J. H., Kim, S. U., \& Mun, H. T. (2003). A study on the carbon budget in Pinus koreansis plantation. Journal of Ecology and Environment, 26(3), 129-134.

Raich, J. W. \& Potter, C. S. (1995). Global patterns of carbon dioxide emission from soil. Global Biochemical Cycle, 9(1), 23-36.

Rodin, L. E., \& Bazilevich, N. I. (1967). Production and mineral cycling in terrestrial vegetation. London: Oliver and Boyd.

Roh, Y. H., Kim, C. K., \& Hong, H. J. (2016). Time-series changes to ecosystem regulating services in Jeju: focusing on estimating carbon sequestration and evaluating economic feasibility. Journal of Environmental Policy and Administration, 24(2), 29-44.

Schmitt, M. D. C., \& Grigal, D. F. (1981). Generalized biomass estimation equations for Betula papyrifera Marsh. Canadian Journal of Forest Research, 11(4), 837-840.
Shin, C. H. (2012). Carbon budget and nutrient cycling in Quercus mongolica forest at Mt. Worak National Park. Ph.D. Dissertation. Korea: Kongju National University.

Son, Y. M., Kim, R. H., Kang, J. T., Lee, K. S., \& Kim, S. W. (2014). A practical application and development of carbon emission factors for 4 major species of warm temperate forest in Korea. Journal of Korean Forest Society, 103(4), $593-598$.

Song, S. T., \& Yoon, S. (2002). Lavas in Gotjawal terrain, Jeju Island, Korea no. 1. Jocheon-Hamdeok Gotjawal terrain. Journal of the Geological Society of Korea, 38(3), 377-389.

Tritton, L. M. and Hornbeck, J. W. (1982). Biomass equations for major tree species of the northeast. United States Department of Agriculture Forest Service. Northeastern Forest Experiment Station. General Technical Report NE-69.

Vandewlle, M., Sykes, M. T., Harrison, P. A., Luck, G. W., Berry, P., Bugter, R. Dawson, T. P., Feld, C. K., Harrington, R., Haslett, J. R., Hering, D., Jones, K. B., Jongman, R., Lavorel, S., Martins da Silva, P., Moora, M., Paterson, J., Rounsevell, M. D. A., Sandin, L., Settele, J., Sousa, J. P. and Zobel, M. (2009). Review paper on concepts of dynamic ecosystems and their services. The RUBICODE Project: Rationalising Biodiversity Conservation in Dynamic Ecosystems.

Wang, G., Qian, J., Cheng, G., \& Lai, Y. (2002). Soil organic carbon pool of grassland on the Qinghai-Tibetan plateau and its global implication. The Science of the Total Environment, 291, 207-217.

Wang, X., Nakatsubo, T., \& Nakane, K. (2012). Impacts of elevated $\mathrm{CO}_{2}$ and temperature on soil respiration in warm temperate evergreen Quercus glauca stands: An open-top chamber experiment. Ecological Research, 27(3), 595-602.

Waring, R. H., \& Schlesinger, W. H. (1987). Forest ecosystems. New York: Academic Press. Inc.

Wattage, P. (2011). Valuation of ecosystem services in coastal ecosystems: Asian and European perspectives. Ecosystem Services Economics. Working Paper Series.

Won, H. Y. (2015). Valuation of ecosystem services through organic carbon distribution and cycling in the Quercus mongolica, Quercus variabilis and Pinus densiflora Forest at Mt. Worak National Park. Ph.D. Dissertation. Korea: Kongju National University.

Won, H. Y., Kim, D. K., Han, A., Lee, Y. S., \& Mun, H. T. (2016). Distribution and absorption of organic carbon in Quercus mongolica and Pinus densiflora forest at Mt. Gumgang in Seosan. Korean Journal of Environment and Ecology, 30(2), 243-252

Won, H. Y., Lee, Y. S., \& Mun, H. T. (2015). Valuation of ecosystem services through organic carbon distribution and cycling in the Pinus densiflora Forest in Mt. Worak National Park. Journal of Wetlands Research, 17(4), 332-338.

Won, H. Y., Oh, K. H., Pyo, J. H., \& Mun, H. T. (2012). Decay rate and nutrient dynamics during litter decomposition of Quercus acutissima and Quercus mysinaefolia. Korean Journal of Environment and Ecology, 26(1), 74-81.

Won, H. Y., Shin, C. H., \& Mun, H. T. (2014). Valuation of ecosystem services through organic carbon distribution and cycling in the Quercus mongolica Forest at Mt. Worak National Park. Journal of Wetlands Research, 16(3), 315-325.

Wunder, S. (2005). Payment for environmental services: Some nuts and bolts. CIFOR Occational Paper. NO. 42

Yun, J. H., Kim, J. H., Oh, K. H., \& Lee, B. Y. (2011). Distributional change and climate condition of warm-temperate evergreen broad-leaved trees in Korea. Korean Journal of Environment and Ecology, 25(1), 047-056.

\section{Ready to submit your research? Choose BMC and benefit from}

- fast, convenient online submission

- thorough peer review by experienced researchers in your field

- rapid publication on acceptance

- support for research data, including large and complex data types

- gold Open Access which fosters wider collaboration and increased citations

- maximum visibility for your research: over $100 \mathrm{M}$ website views per year

At BMC, research is always in progress.

Learn more biomedcentral.com/submissions 